\title{
Cytogenetic analysis of three sea catfish species (Teleostei, Siluriformes, Ariidae) with the first report of Ag-NOR in this fish family
}

\author{
Mauro Nirchio ${ }^{1}$, Emanuel Ricardo Monteiro Martinez ${ }^{2}$, Fausto Foresti ${ }^{2}$ and Claudio Oliveira ${ }^{2}$ \\ ${ }^{1}$ Escuela de Ciencias Aplicadas del Mar, Universidad de Oriente, Isla de Margarita, Venezuela. \\ ${ }^{2}$ Departamento de Morfologia, Instituto de Biociências, Universidade Estadual Paulista \\ "Júlio de Mesquita Filho", Botucatu, SP, Brazil.
}

\begin{abstract}
Despite their ecological and economical importance, fishes of the family Ariidae are still genetically and cytogenetically poorly studied. Among the 133 known species of ariids, only eight have been karyotyped. Cytogenetic analyses performed on Genidens barbus and Sciades herzbergii revealed that both species have $2 \mathrm{n}=56$ chromosomes and Cathorops aff. mapale has $2 \mathrm{n}=52$ chromosomes: Genidens barbus has 10 Metacentrics (M), 14 Submetacentrics (SM), 26 Subtelocentrics (ST), and 6 Acrocentrics (A), Sciades herzbergii has 14M, 20SM, 18ST and 4A, whereas Cathorops aff. mapale has 14M, 20SM, and 18ST. The nucleolus organizer regions (NORs) were found in a single chromosome pair on the short arm of a large-sized ST pair in Genidens barbus and on the short arm of a middle-size SM pair in Cathorops aff. mapale. Multiple NORs on the short arms of two large-sized ST pairs were found in Sciades herzbergii. The occurrence of diploid numbers ranging from $2 n=52$ through 56 chromosomes and the presence of different karyotypic compositions, besides the number and position of NORs suggest that several numeric and structural chromosome rearrangements were fixed during the evolutionary history of this fish family.
\end{abstract}

Key words: cytogenetics, Ag-NORs, chromosome evolution, chromosome rearrangements, fish.

Received: May 5, 2009; Accepted: December 7, 2009.

The order Siluriformes (catfishes) has 3,088 species, divided into 36 families and 477 genera distributed worldwide, except for the coldest areas in the Southern and Northern hemispheres (Ferraris, 2007). There are only two predominantly marine families: Plotosidae and Ariidae. The family Ariidae, know as sea catfishes, includes 133 species distributed in 26 genera. It presents a worldwide distribution with species that live in marine and brackish water (Ferraris, 2007). Recent phylogenetic studies showed that the family Ariidae is monophyletic, but its relationships with other siluriforms remain unclear. Some authors suggest a close relationship with Pangasiidae, Ictaluridae, and mainly Anchariidae (de Pinna, 1998; Kailola, 2004; Hardman, 2005; Sullivan et al., 2006; Betancur-R et al., 2007).

Karyotypes of only eight ariid species have been described so far and showed diploid numbers ranging from $2 n$ $=54$ to $2 \mathrm{n}=56$ and complements mainly constituted of biarmed chromosomes (Table 1). Considering the worldwide distribution of Ariidae and its commercial importance, the main objective of the present study was to

Send correspondence to Claudio Oliveira. Departamento de Morfologia, Instituto de Biociências, Universidade Estadual Paulista "Júlio de Mesquita Filho", 18618-000 Botucatu, SP, Brazil. E-mail: claudio@ibb.unesp.br. describe the karyotypes of Cathorops aff. mapale, Genidens barbus, and Sciades herzbergii for a better understanding of the karyotypic evolution and relationships among genera and species in the family.

The species studied were: Genidens barbus ( 3 males and 3 females) from Ubatuba, São Paulo, Brazil $\left(23^{\circ} 26^{\prime} 00.8^{\prime \prime} \mathrm{S} 45^{\circ} 01^{\prime} 01.7^{\prime \prime} \mathrm{W}, \mathrm{LBP} 2338\right)$, Cathorops aff. mapale (4 males) from Isla Margarita, Nova Esparta, Venezuela (1057’39.6” S 64¹0'26.4” W, LBP 6061), and Sciades herzbergii (8 unsexed specimens) from Isla Margarita, Nova Esparta, Venezuela (1057’39.6” S 64¹0'26.4” $\mathrm{W}$, LBP 6060). Fishes were identified and deposited in the fish collection of the Laboratório de Biologia e Genética de Peixes (LBP), Departamento de Morfologia, Instituto de Biociências, Universidade Estadual Paulista, São Paulo, Brazil and Escuela de Ciencias Aplicadas del Mar, Universidad de Oriente, Isla Margarita, Venezuela.

Mitotic chromosome preparations were performed according to the technique described by Foresti et al. (1993). Nucleolar organizer regions (Ag-NORs) were revealed by the silver-staining method (Howell and Black, 1980). The chromosome morphology was determined based on arm ratios, as proposed by Levan et al. (1964), and the chromosomes were classified according to their morphology as Metacentrics (M), Submetacentrics (SM), Subtelocentrics (ST), and Acrocentrics (A). 
Cytogenetic analyses showed that Genidens barbus has $2 \mathrm{n}=56(10 \mathrm{M}+14 \mathrm{SM}+26 \mathrm{ST}+6 \mathrm{~A}-$ Figure 1$)$, Cathorops aff. mapale has $2 \mathrm{n}=52(14 \mathrm{M}+20 \mathrm{SM}+18 \mathrm{ST}-$ Figure 2a), and Sciades herzbergii has $2 \mathrm{n}=56$ $(14 \mathrm{M}+20 \mathrm{SM}+18 \mathrm{ST}+4 \mathrm{~A}$ - Figure 2b). Early karyotypic studies of G. barbus by Gomes et al. (1994, cited as Netuma barba) and $S$. herzbergii by Molina et al. (2004, cited as Hexanematichthys herzbergii) showed the same diploid numbers found in the present study. However, the karyotypic formulae previously described for these species were different from those found here (Table 1). These differences may be due to technical artifacts, such as differences in chromosome condensation, or may be real differences that should be checked in further studies covering the distribution area of these species.

The available data show that diploid numbers range from $2 n=52$ to $2 n=56$ among ariids and that the karyotypes are mainly constituted by biarmed chromosomes (Table 1$)$. The $2 \mathrm{n}=56$ is the most common diploid number among ariids and occurrs in Aspistor parkeri, Bagre bagre, Genidens barbus, G. genidens, and Sciades herzbergii (Table 1). The diploid number $2 \mathrm{n}=54$ was reported for three species: Ariopsis felis, Bagre marinus, and Cathorops sp. (Table 1). The occurrence of $2 \mathrm{n}=52$ in Cathorops aff. mapale (present work) represents the lowest diploid number already described for ariids.

Up to now, only two species of Cathorops were cytogenetically investigated: $C$. aff. mapale $(2 \mathrm{n}=52$ - present study) and one unidentified species, Cathorops sp., that has $2 \mathrm{n}=54$ (Gomes et al., 1992). This difference in diploid numbers between species of a single genus was also found in Bagre (Fitzsimons et al., 1988; Gomes et al., 1990) (Table 1), suggesting that this is not a rare phenomenon among ariids. On the other hand, the two Genidens species analyzed (Gomes et al., 1994) presented the same diploid number (Table 1).

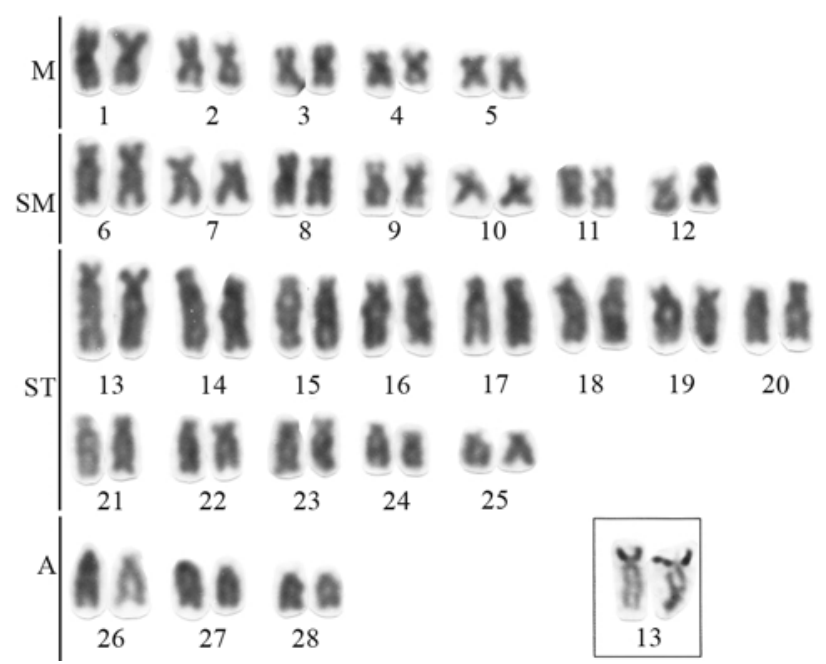

Figure 1 - Giemsa stained karyotype of Genidens barbus with $2 \mathrm{n}=56$ chromosomes. In the inset, silver stained chromosomes showing the terminal Ag-NORs (black dots).

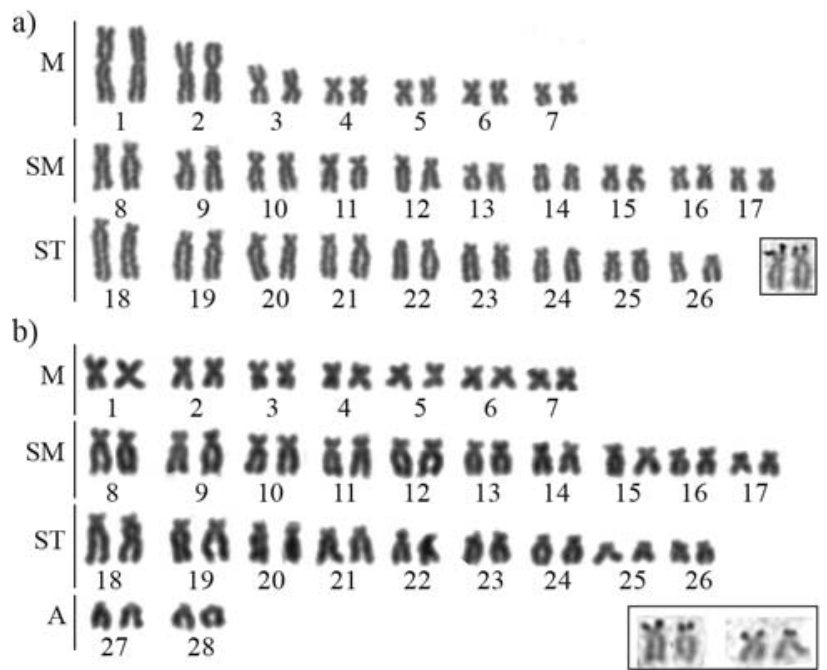

Figure 2 - Giemsa stained karyotypes of (a) Cathorops aff. mapale with $2 \mathrm{n}=52$ chromosomes and (b) Sciades herzbergii with $2 \mathrm{n}=56$ chromosomes. In the inset, silver stained chromosomes showing terminal AgNORs (black dots).

The karyotypes of ariids are composed of all morphological types of chromosomes (Table 1). However, in some species such as those of the genus Bagre and Sciades herzbergii, a large number of metacentric and submetacentric chromosomes is observed, while in other species, such as Bagre marinus, a large number of subtelocentric and acrocentric chromosomes is observed (Table 1). This variation allows to hypothesize that many structural chromosome rearrangements were fixed during the karyotypic evolution among species of this family.

Oliveira and Gosztonyi (2000) studied the karyological evolution of the order Siluriformes, particularly of the family Diplomystidae, and reached the conclusion that the ancestral diploid number for this order is $2 n=56$. Among the families closely related to Ariidae, species of Pangasiidae have about 2n=60 chromosomes (Magtoon and Donsakul, 1987; Manosroi et al. 2003), and among Ictaluridae, the diploid numbers range from $2 n=40$ to 72 (LeGrande and Cavender, 1980; LeGrande, 1981; Clark and Mathis, 1982; LeGrande et al., 1984; Amemiya, 1986). This diploid number variation, as well as that observed among ariids, suggests that numeric chromosome rearrangements (fusions and fissions) may have had an important role in the karyotypic evolution of this group.

The present results on Ag-NORs location are the first described for ariids. The ariid species studied have single or multiple Ag-NORs (Table 1). The NORs were found on the short arm of a biggest-size ST pair in Genidens barbus, and on the short arm of a middle-size SM pair in Cathorops aff. mapale. Among the Ictaluridae species, only single NORbearing chromosomes have been observed (Amemiya et al., 1986). This is also the most common condition in Siluriformes (Oliveira and Gosztonyi, 2000; Oliveira et al., 2006) and even in Teleostei (Klinkhardt, 1998). On the other hand, multiple NORs on the short arm of two large- 
Table 1 - Cytogenetic data available for the family Ariidae. Names in parentheses are original citations corrected in the present study.

\begin{tabular}{|c|c|c|c|c|c|}
\hline Species & Locality & $2 n$ & Karyotype & NORs & References \\
\hline Ariopsis felis $(=$ Arius felis $)$ & Caminada Bay, Louisiana, USA & 54 & $26 \mathrm{M} / \mathrm{SM}+28 \mathrm{ST} / \mathrm{A}$ & - & LeGrande (1980) \\
\hline Aspistor parkeri (= Arius parkeri) & Cananéia Coast, São Paulo, Brazil & 56 & $16 m+16 s m+22 s t+2 t$ & - & Gomes et al. (1994) \\
\hline Bagre bagre & Cananéia Coast, São Paulo, Brazil & 56 & $24 \mathrm{M}+26 \mathrm{SM}+6 \mathrm{ST}$ & - & Gomes et al. (1990) \\
\hline Bagre marinus & Northern Gulf of Mexico, Louisiana, USA & 54 & $12 \mathrm{~m}+8 \mathrm{sm}+34 \mathrm{STT}$ & - & Fitzsimons et al. (1988) \\
\hline Cathorops aff. mapale & Isla Margarita, Venezuela & 52 & $14 \mathrm{~m}+20 \mathrm{sm}+18 \mathrm{st}$ & 1 & Present study \\
\hline Cathorops sp. & Cananéia Coast, São Paulo, Brazil & 54 & $13 m+13 s m+28 s t$ & - & Gomes et al. (1992) \\
\hline Genidens barbus (= Netuma barba) & Cananéia Coast, São Paulo, Brazil & 56 & $18 \mathrm{M}+18 \mathrm{SM}+18 \mathrm{st}+2 \mathrm{~T}$ & - & Gomes et al. (1994) \\
\hline Genidens barbus & Ubatuba Coast, São Paulo, Brazil & 56 & $10 \mathrm{~m}+14 \mathrm{sm}+26 \mathrm{st}+6 \mathrm{a}$ & 1 & Present study \\
\hline Genidens genidens & Cananéia Coast, São Paulo, Brazil & 56 & $12 \mathrm{~m}+20 \mathrm{sm}+20 \mathrm{st}+4 \mathrm{t}$ & - & Gomes et al. (1994) \\
\hline $\begin{array}{l}\text { Sciades herzbergii }(= \\
\text { Hexanematichthys herzbergii) }\end{array}$ & Maracaibo Lake, Venezuela & 56 & $24 \mathrm{M}+24 \mathrm{SM}+6 \mathrm{st}+2 \mathrm{~T}$ & - & Molina et al. (2004) \\
\hline Sciades herzbergii & Isla Margarita, Venezuela & 56 & $14 \mathrm{~m}+20 \mathrm{sm}+18 \mathrm{st}+4 \mathrm{a}$ & 2 & Present study \\
\hline
\end{tabular}

$2 \mathrm{n}$ = diploid number; $\mathrm{M}=$ metacentrics; $\mathrm{SM}=$ submetacentrics; $\mathrm{ST}=$ subtelocentrics; $\mathrm{A}=$ acrocentrics; $\mathrm{T}=$ telocentrics; $\mathrm{STT}=$ subtelo-telocentrics; NORs $=$ number of chromosome pairs with nucleolus organizer regions.

sized ST pairs were found in Sciades herzbergii, which reinforces the hypothesis that structural chromosome rearrangements were also fixed in the karyotypic evolution of ariids.

Chromosomal rearrangements, indicated by differences in diploid numbers and karyotypes among species and by morphological changes in the position of the AgNORs, are widespread among fishes of the family Ariidae (Table 1). These chromosome rearrangements may have played an important role in the karyotypic evolution of the family, as already suggested by LeGrande (1980) and Fitzsimons et al. (1988). However, additional data should be added to clarify the importance of these chromosomal rearrangements in the evolution of the species and genera of ariids.

\section{Acknowledgments}

The authors are grateful to Alexandre Pires Marceniuk for his assistance in identifying the specimens and to R. Devidé for technical assistance. Funds supporting this study were provided by Fundação de Amparo à Pesquisa do Estado de São Paulo (FAPESP), Escuela de Ciencias Aplicadas del Mar, Universidad de Oriente, Isla de Margarita, Venezuela, Conselho Nacional de Investigação Científica $(\mathrm{CNPq})$ and Coordenadoria de Apoio à Pós-Graduação e Pesquisa (CAPES).

\section{References}

Amemiya CT, Kelsch SW, Hendricks FS and Gold JR (1986) The karyotype of the Mexican blindcat, Prietella phreatophila Carranza (Ictaluridae). Copeia 4:1024-1028.

Betancur-R R, Acero AP, Bermingham E and Cooke R (2007) Systematics and biogeography of New World sea catfishes (Siluriformes, Ariidae) as inferred from mitochondrial, nuclear, and morphological evidence. Mol Phylogenet Evol 45:339-357.
Clark B and Mathis P (1982) Karyotypes of middle Tennessee bullheads: Ictalurus melas and Ictalurus natalis (Cypriniformes, Ictaluridae). Copeia 2:457-460.

Ferraris CJ (2007) Checklist of catfishes, recent and fossil (Osteichthyes, Siluriformes), and catalogue of siluriform primary types. Zootaxa 1418:1-628.

Fitzsimons JM, LeGrande WH and Korth JW (1988) Karyology of the marine catfish Bagre marinus (Ariidae) with an analysis of chromosome numbers among siluriform fishes. Jap J Ichthyol 35:189-193.

Foresti F, Oliveira C and Almeida-Toledo LF (1993) A method for chromosome preparations from large specimens of fishes using in vitro short treatment with colchicine. Experientia 49:810-813.

Gomes V, Phan VN and Passos MJAC (1990) The karyotype of a marine catfish, Bagre bagre, from Brazil. Jap J Ichthyol 37:321-326.

Gomes V, Phan VN and Passos MJAC (1994) Karyotypes of three species of marine catfishes from Brazil. Bolm Inst Oceanogr USP 42:55-61.

Gomes V, Phan VN and Passos MJACR (1992) A karyotype of Cathorops sp., a marine catfish from Brazil. Bolm Inst Oceanogr USP 40:87-91.

Hardman M (2005) The phylogenetic relationships among nondiplomystid catfishes as inferred from mitochondrial cytocrome b sequences; the search for the ictalurid sister taxon (Otophysi, Siluriformes). Mol Evol 37:700-720.

Howell WM and Black DA (1980) Controlled silver-staining of nucleolus organizer regions with a protective colloidal developer: A 1-step method. Experientia 36:1014-1015.

Kailola PJ (2004) A phylogenetic exploration of the catfish family Ariidae. The Beagle Rec Mus Art Galleries N Terr 20:87166.

Klinkhardt M (1998) Some aspects of karyoevolution in fishes. An Res Dev 47:7-36.

LeGrande HW, Dunham RA and Smitherman RO (1984) Karyology of three species of catfishes (Ictaluridae, Ictalurus) and four hybrid combinations. Copeia 4:873-878.

LeGrande WH (1980) The chromosome complement of Arius felis (Siluriformes, Ariidae). Jap J Ichthyol 27:82-84. 
LeGrande WH (1981) Chromosomal evolution in North American catfishes (Siluriformes, Ictaluridae) with particular emphasis on the madtoms, Noturus. Copeia 1:33-52.

LeGrande WH and Cavender TM (1980) The chromosome complement of the stonecat madtom, Noturus flavus (Siluriformes, Ictaluridae), with evidence for the existence of a possible chromosomal race. Copeia 2:341-344.

Levan A, Fredga K and Sandberg AA (1964) Nomenclature for centromeric position on chromosomes. Hereditas 52:201220.

Magtoon W and Donsakul T (1987) Karyotypes of pangasiid catfishes, Pangasius sutchi and P. larnaudii, from Thailand. Jap J Ichthyol 34:396-398.

Manosroi J, Meng-Umphan K, Meevatee U and Manosroi A (2003) Chromosomal karyotyping from peripheral blood lymphocytes of the Mekong giant catfish (Pangasianodon gigas, Chevey). Asian Fish Sci 16:241-246.

Molina J, Molero T, Hernández L, Acosta D, Hernández J and Villamediana P (2004) Cariótipo del bagre guatero Hexanematichthys herzbergii (Ariidae, Siluriformes) del estrecho del lago de Maracaibo, Venezuela. Bolm Centro Invest Biol 38:163-174.
Oliveira C and Gosztonyi AE (2000) A cytogenetic study of Diplomystes mesembrinus (Teleostei, Siluriformes, Diplomistidae) with a discussion of chromosome evolution in siluriforms. Caryologia 53:31-37.

Oliveira C, Almeida-Toledo L and Foresti F (2006) Karyotypic evolution in Neotropical fishes. In: Pisano E, Ozouf-Costaz C, Foresti F and Kapoor BG (eds) Fish Cytogenetics. Science Publishers, Enfield, pp 111-164.

de Pinna MCC (1998) Phylogenetic relationships of Neotropical Siluriformes (Teleostei, Ostariophysi): Historical overview and synthesis of hypotheses. In: Malabarba LR, Reis RE, Vari RP, Lucena ZMS and Lucena CAS (eds) Phylogeny and Classification of Neotropical Fishes. Edipucrs, Porto Alegre, pp 279-330.

Sullivan JP, Lundberg JG and Hardman M (2006) A phylogenetic analysis of the major groups of catfishes (Teleostei, Siluriformes) using rag1 and rag2 nuclear gene sequences. Mol Phylogenet Evol 41:636-662.

Associate Editor: Yatiyo Yonegaga-Yassuda

License information: This is an open-access article distributed under the terms of the Creative Commons Attribution License, which permits unrestricted use, distribution, and reproduction in any medium, provided the original work is properly cited. 